\title{
A Measurement Model of Operational Capabilities in Application Software Firms
}

\author{
Keonhyeong Lee ${ }^{1}$ \\ ${ }^{1}$ School of Economics and Management, Tsinghua University, Beijing, China \\ Correspondence: Keonhyeong Lee, School of Economics and Management, Tsinghua University, Beijing, \\ 100084, China. E-mail: ken.07@sem.tsinghua.edu.cn
}

Received: October 6, 2015

Accepted: October 22, $2015 \quad$ Online Published: November 25, 2015

doi:10.5539/ijbm.v10n12p89

URL: http://dx.doi.org/10.5539/ijbm.v10n12p89

\begin{abstract}
In recent strategy literatures, operational capabilities in the information technology have been mostly interested among academic scholars since newly developed mobile devices emerged. However, the conceptualization and measurement of operational capabilities in application software firms has little come to attention. The purpose of this study is to propose a measurable model of operational capabilities by conceptualizing, operationalizing, and measuring operational capabilities. Specifically, based upon theoretical and practical literatures, this study seeks to conceptualize a set of capabilities-organizing, managing, and technical capability-that help operating existing capabilities in the application software business. Moreover, it concretizes the construct of operational capabilities with formulating reflective and formative modes, and also certifies their validities through empirical data-driven testing from 227 mobile software developers, sourced from Mac App Store and Google Android Apps. In the measurement model, it results in reflective indicators as first-order model and formative indicators as second-order model using partial least square analysis techniques. Lastly, the author discusses the theoretical and managerial implications and provide some suggestions for the future study.
\end{abstract}

Keywords: application software, operational capabilities, pls-sem

\section{Introduction}

Developing a new software product or service is a strategic business activity to decide the future survival of IT firms. The evolution of existing software firms and newly emerged mobile firms lead structural changes in development of softwares with making their own mobile development rules. Over recent years, IT firms developing a mobile product or service have made a significant contribution to building IT business ecosystem, which in turn has changed firm's work pattern. With the newly emerging IT markets, firms need to provide on-demand service for customers with fast organizing and managing their resources, capabilities, and embedded routines. Especially, an electronic product or service market sparkled with the launch of new mobile devices, such as smartphone and iPad, continues to reshuffle current business ecosystem to boundless markets. These changes attracted attention for mobile network providers, telecommunication service providers, and mobile software developers. Under these moves, IT firms need to re-equip more systematic product (or service) development capabilities different with previous development activities.

In addition to practical background, theoretical backgrounds regarding capabilities are investigated in relevant to dynamic capabilities since developing conceptual framework on operational capabilities (hereafter, OC) is the one of core issues in dynamic capabilities (Teece, Pisano, \& Shuen, 1997), which are indistinguishable due to embodied routines. Research on dynamic capabilities has developed in the middle of advance and criticism (Helfat et al., 2007) and suggested theoretically conceptual framework on how their existing resources and capabilities transform with changing business environments (Teece et al., 2007). Academic scholars have taken research with different perspectives on associated processes of OC (Easterby-Smith \& Prieto, 2008; Pavlou \& Sawy, 2011; Wu, Melnyk, \& Swink, 2012). The one of existing research gaps from previous research so far is that there was not studied conceptual framework that outlines the specific capabilities in order to fully realize mobile software developing activities. And also, there is little evidence of studies on the OC at an application software business level. Especially, the empirical studies conducted with insufficient measurement model of OC also resulted in discordance between conceptual and empirical research. For all those reasons, the role of OC became more ambiguous. These reasons are why studies on model for OC need urgently (Arend \& Bromiley, 
2009). As well, there urgent need to theoretically verify previous research and empirically examine models for OC since they have an ambiguous conceptualization.

To search for a model to conceptualize and operationalize OC based upon previous theoretical reviews is a main objective in this study. In particular, there is still not much empirical research about OC in new mobile product or service development and also does not much ones to verify pervious research. Pavlou and El Sawy (2011) suggested conceptual frameworks of $\mathrm{OC}$ and their sub-dimensions in the context of new product development. Extending its study on OC into mobile IT products or service field, this study seeks to suggest a measurement model of $\mathrm{OC}$ to clarify its construct. In particular, it addresses the question of what the construct and sub-constructs of $\mathrm{OC}$ and how they interact to make a business unit workable in software application firms. That is to say, it focuses on exploring conceptual framework of OC from application software developers and their firms based upon strategic management literatures and practical perspectives. The specific research questions are what $\mathrm{OC}$ are, how their sub-capabilities work, and those constructs are supported by the empirical testing. The objective of this study is not only to theoretically establish and explain the construct and sub-dimensions of OC, but also to empirically validate them in new mobile application software product or service development context. This study endeavors to offer clarity to the construct of OC in application software firms by arguing for the enabling factors that collectively make up the construct. This study explains that the constructs are organized at different levels, and that these capabilities can be observed in each business setting. It is mostly in the recent literature that we find suggestions to what may be the constructs within operational capability in the context of new product or service development (Fischer, Gebauer, Gregory, Ren, \& Fleisch, 2010; Pavlou \& Sawy, 2011).

This research question focuses on conceptual issues on $\mathrm{OC}$, which have been not agreed among scholars since OC per se gradually and tacitly changes with previous capabilities embodied, which obviously represent differently among firms. Wu et al. (2010) assert that OC have "firm-specific sets of skills, processes, and routines" (p. 726) to deal with facing problems so that can reconfigure resources. In order to overcome of obstacles with these classifications and measuring indicators (Eisenhardt \& Martin, 2000; Helfat \& Winter, 2011), this study tries to develop conceptual framework of OC in the context of application software development firms based upon some analogous to $\mathrm{Wu}$ et al. (2010) study. It divides into three sub-capabilities of OC which involves organizing, managing, and technical capabilities. The study develops knowledge by investigating these capabilities at the second-order latent construct level of abstraction.

\section{Capabilities}

Operational capabilities have traits that can be difficult to measure exactly even though they are keys to perform IT business. This study focuses mainly on OC to develop the conceptual construct in a way that is easy to recognize in application developing business. It first concisely separates between OC and other accompanied concepts such as capabilities and resources, focusing on implications for managers. Capabilities used in resource based view literatures are regarded as "the tangible and intangible assets that enable a firm to fully exploit the other resources it controls" (Barney \& Hesterly, 2009; Rumelt, 1984; Teece, 1982). In other studies, capabilities are regarded as "collections of routines" or "a high-level routine" (Winter, 2003, p. 991) in which routines have traits of repetitious patterns, and viewed as "all regular and predictable behavioral patterns of firms" (Nelson \& Winter, 1982, p. 14), which means organizations' daily activities to deal with tasks. Wang $(2007$, p. 35) refer it as "a firm's capacity to deploy resources" in explicit and implicit processes. Hence, capabilities are often regarded as firm-specific and are advanced by reciprocal actions among the firm's resources as time passes (Amit \& Schoemaker, 1993, p. 35). "A capability, whether operational or dynamic, is the ability to perform a particular task or activity (Helfat et al., 2007; Leonard-Barton, 1992; Prahalad \& Hamel, 1990)."

Some distinctive capabilities lead firms to take a better stance in competitive markets, where firms with heterogeneous capabilities (Barney, 1991; Henderson \& Clark, 1990; Henderson \& Cockburn, 1994; Peteraf, 1993; Teece et al., 1997; Wernerfelt, 1984) over homogeneous capabilities (Barney, 1991; Eisenhardt \& Martin, 2000; Winter, 2003) are regarded as better performance. In order to clarify differences among capabilities concepts, this study tries to distinguish dispersed concepts into three general types. Generic capabilities are used in firms' value chain whose abilities support secondary activities in each stage' function (Grant, 1996; Helfat \& Peteraf, 2009; Porter, 1985; Wang \& Ahmed, 2007). OC is the ability to do day-to-day activities (Arend \& Bromiley, 2009; Bowman \& Ambrosini, 2003; Easterby-Smith, Lyles, \& Peteraf, 2009; Helfat et al., 2007; Wang \& Ahmed, 2007; Winter, 2003; Zahra, Sapienza, \& Davidsson, 2006). Dynamic capabilities are "the ability to integrate, build, and reconfigure internal and external resources to turbulent environment" (Teece et al., 1997, p. 516).

Generic capabilities have a broad scope of capabilities, in particular, general capabilities are applied to $R \& D$, 
product design, manufacturing, marketing, logistics, and service used in value chain activities as the classification of functional area in which they include primary (e.g. inbound logistics, buying, inventory, outbound logistics; warehouse and distribution, selling, marketing, and service etc.) and support activities (e.g. infrastructures: planning, finance, information, service, legal; human resource management; R\&D, product design). It plays a role to seize comprehensive system only using value chain perspective. Most of capabilities are believed to stem from generic capabilities, in contrary to, operational (ordinary) capabilities (cf. Collis, 1994; Winter, 2003; Zollo \& Winter, 2002) are thought as collection of routines activities, which result in distinct traits between generic and OC (Drnevich \& Kriauciunas, 2011). In addition, it is necessary to distinguish dynamic and OC, as the stated above, OC are collection of routines (Winter, 2000) and exploitation of existing resources (March, 1991), whereas dynamic capabilities are the exploration of new opportunities and reconfiguring existing OC to turbulent environment (Collis, 1994).

\section{Theoretical Review on Operational Capabilities}

It is operational capabilities per se that is the chief obstacles in conceptualizing and measuring the index of operational capabilities. That is, there is in trouble converting existing OC that have been executed existing business into new ones due to changes in the environment. There are two major issues of the latest argument on OC. One is that OC per se attempt to change, and the other one is that dynamic capabilities are only realized by the course of OC. Winter (2003) has opinion that OC themselves can come true the performance, but her recent study presents that the classification of various capabilities should be carefully treated in each study due to varied environments and wide ranges of OC (Helfat \& Winter, 2011). The relevant studies still did not make concrete progress. However, the common part of OC and dynamic capabilities is regarded as the ability to perform the task, as it reviewed in the above capabilities conceptual section. This study adopts the concept of OC suggested by Helfat and Winter (2011) to apply to one IT area. In other words, it deals mainly with on OC in the mobile application software development firms within IT field. OC are embraced as the lower part concept of organizational capabilities that depend on what companies operate businesses. Organizational capabilities have characteristics that don't change at speedy but advance in steady over time, which come into sight as an accumulated form in each firm business (Flynn, Wu, \& Melnyk, 2010).

To avoid confusion of operational relevant terms, operational practice is defined as the standard process to achieve the goals of task. Before explaining OC, their recent managerial views are based upon organizational capabilities perspective (Eisenhardt \& Martin, 2000; Helfat et al., 2007; Teece, 2007). OC are regarded as distinctive abilities, which in direct associate with competitive advantage of firms, which are achieved through continuous organizational learning and process such as absorbing know-how and skills. That is, firms owning rare and inimitable resources and capabilities can keep sustainable market predominance. Its organizational capability are also based from the similar theories as dynamic capabilities, which are resourced based view by Barney (1991) that were developed from Wernerfelt (1984) influenced by firms' growth theory (Penrose, 1959).

Table 1 explains concepts that are more specific about OC. Collis (1994) suggests two categories of capabilities such as ordinary, dynamic activities. Zollo and Winter (2002) and Winter (2003) express capabilities into higher order capabilities in the sequence of operational and dynamic capabilities. OC plays a huge role in doing business activities to improve efficiency and effectiveness of firms' performance. Through OC, firms obtain profits from business markets, which in turn facilitates firms to repeat the business operations. As the above stated, this study divide capabilities into three concepts in which they are regarded as the ability to perform daily task activities. 
Table 1. Main selected definition of operational capabilities

\begin{tabular}{|c|c|c|}
\hline Authors(Year) & Definition & Remarks \\
\hline Collis (1994) & $\begin{array}{l}\text { "An ability to perform the basic functional activities of } \\
\text { the firm" as the first category of organizational } \\
\text { capabilities }\end{array}$ & $\begin{array}{l}\text { Two type of organizational capabilities: OC; } \\
\text { dynamic capabilities, which were differentiated and } \\
\text { named by Winter (2003) and Zollo \& Winter (2002) }\end{array}$ \\
\hline March (1991) & The efficient exploitation of existing resources & $\begin{array}{l}\text { Dynamic capabilities as the exploration of new } \\
\text { opportunities }\end{array}$ \\
\hline Winter (2003) & The ability to "make a daily living" & Ordinary or “zero-order" capabilities \\
\hline Wu et al. (2010) & $\begin{array}{l}\text { "Firm-specific sets of skills, processes, and routines to } \\
\text { solve problems through configuring operational } \\
\text { resources." }\end{array}$ & $\begin{array}{l}\text { OC dimensions were extracted from functional activities } \\
\text { in China Quanjude restaurant }\end{array}$ \\
\hline Pavlou (2011) & "The ability to execute day-to-day activities" & New product development context \\
\hline Martin (2011) & $\begin{array}{l}\text { "The capacity to exploit resource base through learning } \\
\text { and refining the processes, procedures, skills, and } \\
\text { incentive systems necessary to repeat, leverage, and } \\
\text { sustain past successes." }\end{array}$ & $\begin{array}{l}\text { Based upon Collis (1994) and Winter (2003), } \\
\text { Theory-building multiple case-study }\end{array}$ \\
\hline
\end{tabular}

\section{Research Model of Operational Capabilities}

Based upon definition of $\mathrm{OC}$ as mentioned above, it was explored through the literature for OC. Our starting points are researches conducted by Flynn, Wu et al. (2010), Wu, Melnyk et al. (2010; 2012), and Pavlou and El Sawy (2011). This study in regard to dimensions of OC applies the approaches proposed by their works since different labels about OC have been applied in preceding research to refer to related practices, routines, and OC, and then merged several conceptual labels from practical and theoretical reviews, and classified them to a parsimonious set in order to propose OC conceptualization, its own interpretation in this study. Although these works provide clues to the approach to construct a model of OC, several capabilities among them require further modification to fit their dimensionalities in this study. Therefore, this study introduces the basic functional activities drawn from the literatures on OC. This study suggests 3-dimensions on OC: organizing, managing, and technical capabilities, which they are proposed in the following literature studies.

\subsection{Organizing Capabilities}

Organizing capabilities is a set of capabilities to match and arrange firms' resources and assets to build a unified activity to the right ways. Organizing relates to integration as the ability to coordinate and integrate firms' resources and assets (Bowman \& Ambrosini, 2003) and as "the ability to combine individual knowledge into the unit's new OC (Pavlou \& Sawy, 2011)." For application software development context, it has processes in which managers make working units to combine their skills, expertise, assets, and resources to create new software or service, and they make integrated and linked components into "a coherent whole" (Henderson \& Clark, 1990). Quinn and Dutton (2005) noted that coordination is the process of "arranging activities" to achieve their goals (p. 36). Pavlou and El Sawy (2011) define it as "the ability to orchestrate and deploy tasks, resources, and activities in the new OC," (p. 246) which consists of the basic routines such as assigning, appointing, identifying, and orchestrating tasks, resources, and activities. Once integrating new knowledge in collective levels, it requires a decision to arrange existing or newly created knowledge with coordination. In the context of newly developing software, they must participate in coordinating to make their working process with effect and to manipulate existing resources and capabilities to initiate new products or service. Coordination improves the ability of development units to deploy their mutual activities and there have different distinction between integrating and coordination (Kogut \& Zander, 1996), which are that coordinating capabilities describe distinct activities to orchestrate individual tasks and activities whereas integrating capabilities have different activities, which build a unified understanding of tasks, resources, and activities.

In this study, organizing capabilities consist of five basic routines. First, combination to the developing apps units helps collect and combine individual resources, skills, and knowledge. "Combinative capabilities" explain how to apply existing knowledge resources to interconnect among each unit, develop, and create new ones (Kogut \& Zander, 1992). Second, acquaintance builds a common understanding of mutual tasks and duties to promote new product or service effectively. Third, matching helps in avoiding the overlap of similar tasks and develops the work process efficiently. Fourth, assigning resources to tasks (Helfat \& Peteraf, 2003) enables developing units to enable flexibility of new product development (Okhuysen \& Eisenhardt, 2002). Fifth, appointing the right person to the right task as "patching" as a process strategy (Eisenhardt \& Brown, 1999) helps in operating application software development units effectively. 


\subsection{Managing Capabilities}

Managing capabilities is a set of capabilities to respond, monitor, and manage unexpected circumstances or activities related with development of new application softwares. Swink and Hegarty (1998) mentioned responsiveness as the ability to reconcile the process of producing products with variation of input or output requisite under the unexpected changes. Response capabilities are regarded as the tool to quickly realign the organization's resources in order to react to environmental changes or prevent terrible events. A strategic response capability is the ability to cope with various risks existed around the firms' activities which leads to suffer. With strategic response capabilities, firms can take advantage of new chances to market or technologies and take threatening factors away. Bettis (1995) defined strategic response capability as "the generalized ability to respond fast when change or surprise occurs," and is a main factor to fitness for survival (1995, pp. 15-16). $\mathrm{Wu}$ et al. (2010) suggested operational responsiveness as the quick response to handle tangible or intangible to consistently meet customer requirements. In the context of new product development, developing software units need more immediate responses to current unexpected incidents or changing environmental work conditions to achieve efficient short-term effects with organized activities, especially, in operating process in product or service development. In the absence of response capabilities, product development units become more and more misarranged with efficient processes, and new technologies don't attune to changing customer needs (Andersen \& Schrøder, 2010). Response capabilities in the application software development level is the ability to cope with unexpected circumstances occurred in the process of producing new product or service. Operational response capabilities improve the ability of new product development units to perform current new product development activities, and it is distinct in that it focuses on using existing resources and assets to avoid disastrous events within current units' conditions contrary to dynamic response capabilities to focus on changing business environments to improve units' outcomes. A monitoring capability is regarded as the one of managerial capabilities in OC literatures in which managers have duties to monitor internal organizational operations and control various events occurred inside the job fields. It enables new product development units to operate a flexible business and can lead to fit inner strategies to changing business environments (Davies \& Brady, 2000). Managerial related capabilities have the broad range including human resource management, financial management, etc., so this study only focuses on managerial capabilities relevant to the working sites. Pavlou and Sawy (2011) used managerial capabilities as the ability to manage three basic activities which consist of supervising and controlling conflicts cited from Danneels' study (2002). Managers require monitoring capabilities to conduct efficient operations by actively collecting employees-related information and monitoring works' patterns, so managers can identify their inefficient points and improve them to the better directions fit to firms' strategies. Operational managerial capabilities are distinct in that it focuses on managing current working routines to endeavor to conduct efficient operation contrary to dynamic managerial capabilities to focus on making a change in resource base in the organization to harmonize with changing business environments (Adner $\&$ Helfat, 2003).

These working process routines related with application software development for the OC literature were proposed through their five basic routines. First, swift managing on the unexpected circumstances during work duties. Second, effective handling the balances of supply and demand related with insufficient resources. Third, effective control of defects within products or service. These routines enable a firm to produce its product or service that customers need in timely manner and allow product development units to operate their tasks efficiently. And also, their working processes relevant to the development of product or service for the OC were proposed through two basic routines as reporting development progress and participating in the field spots. These routines make new product development units more efficient to manage the flow of producing new product or service.

\subsection{Technical Capabilities}

In general, technical capabilities are regarded as technical skills and resources (Song \& Parry, 1997) used in creating products or service and the ability to convert inputs into outputs (Spanos \& Lioukas, 2001, p. 915). Pavlou \& El Sawy (2011) define technical capability as "the ability to physically develop new products by understanding product technologies, evaluating the feasibility of product designs, testing prototypes, and assessing technical specifications" (2011, p. 248) based upon Pisano (1994). Flynn, Wu et al (2010) analyzed OC with "operational improvement" as technical capabilities to search for new methods of doing tasks where main concept is to refine on current operations processes. Operational technical capabilities enable firms to improve their outcomes and meet customer requirements with cost- and time-effectively (Protogerou, Caloghirou, \& Lioukas, 2012). In the absence of its sufficient capability, firms fail to create commercial success (Fowler, King, Marsh, \& Victor, 2000). The core concept of customer capabilities is to keep close customer relationship with firms. 
Customer capabilities is the ability to customize new products or service to gradually fine-tune customer needs. It is essential for new product development working process that is composed of skills and abilities necessary to reach close customer relationship, so well tuned procedures that meet customer's needs are embedded in new products or service. Day (1994) argued customer-linking capabilities as one of distinctive capabilities to improve market orientation (Kohli \& Jaworski, 1990; Narver \& Slater, 1990), which they are the abilities to put new products or service on the market to customers' preferences with the process of designing, developing, and launching.

Their working process relevant to techniques in application software development for the OC was proposed through five basic routines as evaluating competitors' application software and their service, testing prototypes or trial services, evaluating technical specifications and feasibilities, conducting test-markets of application softwares or their service, and modifying products (or service) design or working process, which are based upon customers' needs. These routines make application software development units more efficient to develop technologically and introduce new products or service that customers want, which make firms easier to merchandize new products or service.

\section{Methods}

To address the research questions, a quantitative study was selected. To develop and test questionnaires for OC within IT firms that mainly focus on developing mobile application softwares, this study first reviewed relevant theoretical, practical, and technical literatures before executing a quantitative study.

\subsection{Sample and Data Collection}

Data was achieved utilizing random sampling of developers from IT firms within online software application stores, sourced from Google Android Apps and Mac App Store. It was conducted mainly through online panels since target respondents who took part in all belonged to information technology tasks in order to collect appropriate respondents relevant to this study. IT online respondents have job fields that range from hardware or software developers. Target respondents selected at random from the online application software stores were sent using an e-mail attached the questionnaire or linked the survey web page, and the collection of questionnaires were conducted within three months from January, 2014 to March, 2014. The unit of analysis is the capabilities in firms, which was thought to be suitable to apprehend new IT product and service development. To measure capabilities in the developing process of products or service, IT firms were selected in this study, which are similar to previous studies conducted by Pavlou (2010) and Wu et al. (2011).

With examining data examination that includes missing value, suspicious pattern data, and data distribution, a final effective sample size of 227 responses from initially randomized selected 3611 target respondents were used in analyzing this empirical study. Based upon Li et al. (2010) category, application software product and service were divided into three sectors: visual \& audio applications (15\%), decision support applications (18.5\%), infrastructure software (30.8\%) such as network, utilities, and operating systems, life application (12.8\%), and others (19.4\%). An investigation of the sample features indicates that the gender of respondents ranges $57.7 \%$ for males and $38.8 \%$ for female. The level of education ranges from less than high school to graduate school, which the respondents over college degrees occupied around $86 \%$ of all target respondents. Respondents' work experience shows that $74.9 \%$ has experience relevant with development of product or service below 15 years. The actual months taken for development project completion of your IT products (or service) show that $81.4 \%$ firms completed their new product or service projects less than 1 year and $14.9 \%$ firms spent over 1 year accomplishing their project.

\subsection{Analysis}

The analytical methodology involves Partial Least Squares-Structural Equation Modeling (hereafter, PLS-SEM) was selected to treat the complex modeling, non-distributional data patterns, and the directionality of indicators. Other analytical methods used in the study include principal components analysis (hereafter, PCA), exploratory factor analysis (hereafter, EFA) in which SPSS 21 version was used. To analyze the collected data, PLS-SEM techniques using SmartPLS3 (Ringle, Wende, \& Becker, 2015) are applied to this study. This analysis was considered to select PLS-SEM method to handle following issues in which the relationship between indicators and latent variables formulates with formative and reflective modes (Henseler, Ringle, \& Sinkovics, 2009), the data collected from the survey is not normally distributed, the focus in this study is on causal-predictive analysis, and new measurement models for $\mathrm{OC}$ are required due to a relatively new phenomenon and low theoretical information with high complex situations (Fornell \& Larcker, 1981; Joseph F Hair, Sarstedt, Pieper, \& Ringle, 2012; Wold, 1980). Further, no empirical research on operational capabilities from application software 
development firms has been addressed yet. Thus, our conceptual framework is not fairly verified in previous research so that PLS-SEM as a statistical analysis tool is the applicable method for empirically exploring it.

To evaluate the reliability and validity of the reflective indicators used in this research, firstly, exploratory factor analysis (EFA) to confirm the unidimensionality of each construct was conducted. The unidimensionality of each construct was checked by EFA whether this study was suitable for an exploratory research. Tenenhaus et al. (2005) used three tools to check the unidimensionality of a block, according to their study, this study also followed them with PCA (principal component analysis), Cronbach's alpha except for Dillon-Goldstein's $\rho$. The measured each indicator converges to the corresponding a factor and its indicator loads to one factor with high proportion than other factors. A block is usually accepted as unidimensionality in the case that 1 st eigenvalue is higher than 1 . Kaiser-Meyer-Olkin (KMO) measure of sampling adequacy is to assess the level of related variables shared with a common factor and their criteria values are between 0 and 1, where the value below 0.50 are not allowed (Kim \& Mueller, 1978). Bartlett's Test of Sphericity (BT) statistics to confirm the data fitness to factor analysis and it can be considered as unidimensionality in the case of $\mathrm{p}<.01$. Cronbach's alpha is a traditional index to confirm the reliability of constructs, and it can be unidimensional if its value is usually more than 0.7 for confirmatory studies and exceeds 0.6 for exploratory studies but its criteria are accepted in different each academic fields. It results in that blocks of OC divide into organizing, managing, and technical capabilities, which support a unitary construct and satisfy the criteria of a block unidimensionality to proceed the next evaluation of measurement models.

Table 2. Check for block unidimensionality

\begin{tabular}{|c|c|c|c|c|c|c|c|}
\hline & $\begin{array}{c}\text { Block } \\
\text { (sub-capabilities) }\end{array}$ & $\mathrm{KMO}$ & $\begin{array}{c}\text { Bartlett's test } \\
\text { (Sig) }\end{array}$ & $\begin{array}{c}\text { 1st } \\
\text { Eigenvalues }\end{array}$ & 2nd Eigenvalue & $\begin{array}{c}\% \text { of } \\
\text { Variance }\end{array}$ & $\begin{array}{c}\text { Cronbach's } \\
\text { Alpha }\end{array}$ \\
\hline \multirow{3}{*}{$\begin{array}{l}\text { Operational } \\
\text { Capabilities }\end{array}$} & Organizing & 0.861 & $<.001$ & 4.133 & 0.838 & 68.885 & 0.921 \\
\hline & Managing & 0.872 & $<.001$ & 4.269 & 0.700 & 71.153 & 0.918 \\
\hline & Technical & 0.902 & $<.001$ & 4.096 & 0.504 & 68.272 & 0.904 \\
\hline
\end{tabular}

\section{Measurement for Operational Capabilities Construct}

OC are conceptualized as reflective-formative type II as to construct their index (Becker, Klein, \& Wetzels, 2012; Diamantopoulos \& Winklhofer, 2001; Diamantopoulos, Riefler, \& Roth, 2008; Ringle, Sarstedt, \& Straub, 2012), which are determined by the decision rules as Jarvis et al.(2003) and Becker et al.(2012) whether a construct is formative or reflective mode (Berghman, Matthyssens, Streukens, \& Vandenbempt, 2013; Chin, 1998; Jarvis et al., 2003). Based upon their guidelines, this section check 4 main points with the process of index construction where there include the causal directionalities of individual construct with its indicators suggested from theoretical concepts, indicators interchangeability, covariation among indicators, and nomological net among the indicators of each construct (Jarvis et al., 2003, p. 203). As conceptualization of OC as suggested as the above research model, three first-order dimensions that consist of organizing, managing, and technical capabilities are causal links to second-order OC index. Each sub-dimension does not share a common content to discriminate their constructs validity and also indicators in each construct represent similar items. Indicators in each construct do not necessary to covary with each other since behaviors in the organizing or the managing construct may influence on following capabilities but do not necessary to have a positive effect on technical capabilities. In nomological net of indicators in each construct, it is not necessary to have the similar antecedents and consequences as in reflective constructs (Jarvis et al., 2003).

As lacks of available scales for measuring the sub-dimensions of OC, each construct is examined whether it is reflective or formative one using index construction and its decision rules based upon Diamantopoulos and Winklhofer's approach (Diamantopoulos et al., 2008). For each construct, based upon Flynn et al. (2010) and Wu et al. (2010; 2012), conceptualization of OC was modified and divided the relevant processes into three dimensions applicable to the objective of this study: organizing, managing, and technical dimension. It then checked whether each first-order construct of the OC index shows reflective or formative measurement modes (mode A or mode B in PLS-SEM). It is necessary to set interchangeable indicators up within each construct since each sub-dimension influences on OC, as the direction of cause from indicators to a construct, is constructed as a formative index. OC per se contains various activities to execute the above stated capabilities and their operating means are also different patterns among each business unit, which make difficult to measure all relevant activities.

To specify the formative index of OC, for organizing, managing and technical capabilities, most applicable items in this study were collected and formulated to assess scales in each sub-dimension drawn from previous relevant literatures. For organizing capabilities, existing coordination and integration scales were drawn from Flynn et al. 
(2010), Pavlou \& Sawy (2011), and Wu et al. (2010) studies, which were suitably modified to use in this study. Five-item reflective scales to measure its capability were used, which included items assessing formation of task and tangible or intangible resources, such as matching tasks, appointing the right staff, effective integrating resources, they are measured as a 7-point scale as agreement. For managing capabilities, existing managerial and responsiveness scales drawn from Pavlou (2011), Wu et al. (2010), and Flynn et al. (2010) were modified to use in this study. Five-item reflective scales to measure its capability were used, which included items assessing basic functional activities in developing IT relevant product or service, such as controlling variously occurring unexpected problems, monitoring and administering tasks or development process of product or service. They are measured using a 7-point scale as agreement level. For technical capabilities, existing scales Pavlou (2006; 2011) were modified to use in this study. Five-item reflective scales to measure its capability were used, which included items assessing functional activities relevant with technological fields before placing product or service on the market, such as multiple-testing, modifying, and evaluating new product or service and competitor's. They are measured using a 7-point scale as agreement level. For each dimension of OC, the selected items all assign to a common theme and are interchangeable within each dimension but not across the three dimensions (Jarvis et al., 2003) through statistical testing in regard of cross loading and discriminant validity (Fornell \& Larcker, 1981) using empirical data testing. Therefore, three sub-dimensions resulted in reflective mode.

\section{Measurement Model for Operational Capabilities}

To evaluate indicator reliability, indicator loadings were assessed. For all constructs, indicator loadings scope of value above the required thresholds of 0.7 (Fornell \& Larcker, 1981; Nunnally, 1978). To evaluate internal consistency, Cronbach's alpha was estimated. For all constructs, their values are above the threshold of 0.7 and show reliable level among each construct. The composite reliabilities are above the necessary level of 0.7 . To evaluate convergent validity, AVE was assessed. For all constructs including technical, organizing, and managing construct as a first-order construct and $\mathrm{OC}$ as the second-order latent construct, the AVE is above the level of 0.5 (Joe F Hair, Sarstedt, Ringle, \& Mena, 2011).

Table 3. Assessment of reflective measurement models for operational capabilities

\begin{tabular}{|c|c|c|c|c|c|c|c|c|c|c|}
\hline Construct & Indicators & Range & Mean & SD & $\begin{array}{c}\text { 1st order } \\
\text { loading }\end{array}$ & $\begin{array}{c}\text { 2nd order } \\
\text { loadings }\end{array}$ & AVE & $\mathrm{CR}$ & $\alpha$ & $\begin{array}{l}\text { AVE }> \\
\text { Corr }^{2}\end{array}$ \\
\hline \multirow{5}{*}{ Technical $^{\mathrm{b}}$} & $\mathrm{t} 1$ & $2-7$ & 5.67 & 1.09 & $0.828^{*}$ & $0.783^{*}$ & \multirow{5}{*}{0.71} & \multirow{5}{*}{0.92} & \multirow{5}{*}{0.89} & \multirow{5}{*}{$\begin{array}{c}0.71> \\
0.53\end{array}$} \\
\hline & $\mathrm{t} 2$ & $2-7$ & 5.56 & 1.20 & $0.843^{*}$ & $0.764^{*}$ & & & & \\
\hline & $\mathrm{t} 3$ & $2-7$ & 5.53 & 1.21 & $0.854^{*}$ & $0.737^{*}$ & & & & \\
\hline & $\mathrm{t} 4$ & $1-7$ & 5.21 & 1.33 & $0.827^{*}$ & $0.696^{*}$ & & & & \\
\hline & t5 & $1-7$ & 5.53 & 1.21 & $0.862^{*}$ & $0.768^{*}$ & & & & \\
\hline \multirow{5}{*}{ Organizing $^{\mathrm{b}}$} & o1 & $1-7$ & 5.46 & 1.15 & $0.879^{*}$ & $0.785^{*}$ & \multirow{5}{*}{0.73} & \multirow{5}{*}{0.93} & \multirow{5}{*}{0.90} & \multirow{5}{*}{$\begin{array}{l}0.73> \\
0.530\end{array}$} \\
\hline & o2 & $1-7$ & 5.48 & 1.22 & $0.864^{*}$ & $0.807^{*}$ & & & & \\
\hline & o3 & $2-7$ & 5.35 & 1.08 & $0.800^{*}$ & $0.769^{*}$ & & & & \\
\hline & o4 & $1-7$ & 5.55 & 1.16 & $0.863^{*}$ & $0.745^{*}$ & & & & \\
\hline & 05 & $1-7$ & 5.52 & 1.18 & $0.854^{*}$ & $0.744^{*}$ & & & & \\
\hline \multirow{5}{*}{ Managing ${ }^{\mathrm{b}}$} & $\mathrm{m} 1$ & $1-7$ & 5.30 & 1.31 & $0.817^{*}$ & $0.765^{*}$ & \multirow{5}{*}{0.73} & \multirow{5}{*}{0.93} & \multirow{5}{*}{0.90} & \multirow{5}{*}{$\begin{array}{r}0.73> \\
0.46\end{array}$} \\
\hline & $\mathrm{m} 2$ & $1-7$ & 5.25 & 1.43 & $0.835^{*}$ & $0.716^{*}$ & & & & \\
\hline & $\mathrm{m} 3$ & $1-7$ & 5.20 & 1.24 & $0.875^{*}$ & $0.756^{*}$ & & & & \\
\hline & $\mathrm{m} 4$ & $1-7$ & 5.08 & 1.32 & $0.881^{*}$ & $0.747^{*}$ & & & & \\
\hline & $\mathrm{m} 5$ & $1-7$ & 5.22 & 1.26 & $0.864^{*}$ & $0.745^{*}$ & & & & \\
\hline $\mathrm{OC}$ & \multicolumn{6}{|c|}{ Second order construct, Repeated indicators approach } & 0.57 & 0.95 & 0.94 & n.s. \\
\hline
\end{tabular}

Note. ${ }^{*}$ Significant at 0.001 (2-tailed). AVE=average variance extracted. Corr ${ }^{2}=$ the highest squared correlation between the model constructs.

${ }^{\mathrm{b}}$ Anchored at $1=$ strongly disagree and $7=$ strongly agree.

n.s. The discriminant validity between Higher-Order Component and the Low-Order Components is unnecessary to be estimated in the repeated indicator approach (Joseph F Hair, Hult, Ringle, \& Sarstedt, 2013)

Bootstrapping settings are 5000 sub-samples, no sign changes, a significance level of 0.01, Bias-corrected and accelerated (BCA) bootstrap of confidence interval method.

To exam whether constructs were satisfactorily distinct from each other, discriminant validity was tested using the Fornell and Larcker (1981) criterion in the manner of techniques, which is the AVE (average variance extracted) of the construct should be greater than the square of the largest correlation value with any construct. All constructs used in this study meet four statistics requirements. Taken together, these results offer acceptable reliability and 
validity that the reflective measurement model well suited for the data. For OC, a composite model second-order index (Type II: reflective-formative type) is used (Wetzels, 2009). In order to identify the hierarchical latent variable OC in PLS-SEM, it conceptualized the hierarchical components model through repeated indicator approach underlying first-order reflective constructs (Tenenhaus et al., 2005). It shows a conceptual representation of the hierarchical components model. Different quality criteria are necessary to evaluate the measurement properties of the formative second-order index, which include internal consistency and convergent validity but they are not appropriate to formative constructs (Bollen \& Lennox, 1991). Thus, multicollinearity using the variance-inflation factors (VIF) was tested (Diamantopoulos \& Winklhofer, 2001). Inspection of the VIFs does not raise issue about multicollinearity, as they are less than the cut-off value of 5 (Joe F Hair et al., 2011) and described in the below table. Also, the weights of all indicators are significant also since negative and positive indicator weights do not co-occur (Cenfetelli \& Bassellier, 2009).

Table 4. Quality criteria of formative measurements

\begin{tabular}{ccccc}
\hline Construct/Item & Number of items & TOF & VIF & Weights \\
\hline Operational Capabilities & & & & $0.372^{*}$ \\
Managing & 5 & 0.486 & 2.058 & $0.369^{*}$ \\
Technical & 5 & 0.423 & 2.364 & $0.383^{*}$ \\
Organizing & 5 & 0.397 & 2.519 & \\
\hline
\end{tabular}

*Significant at 0.001 (2-tailed).

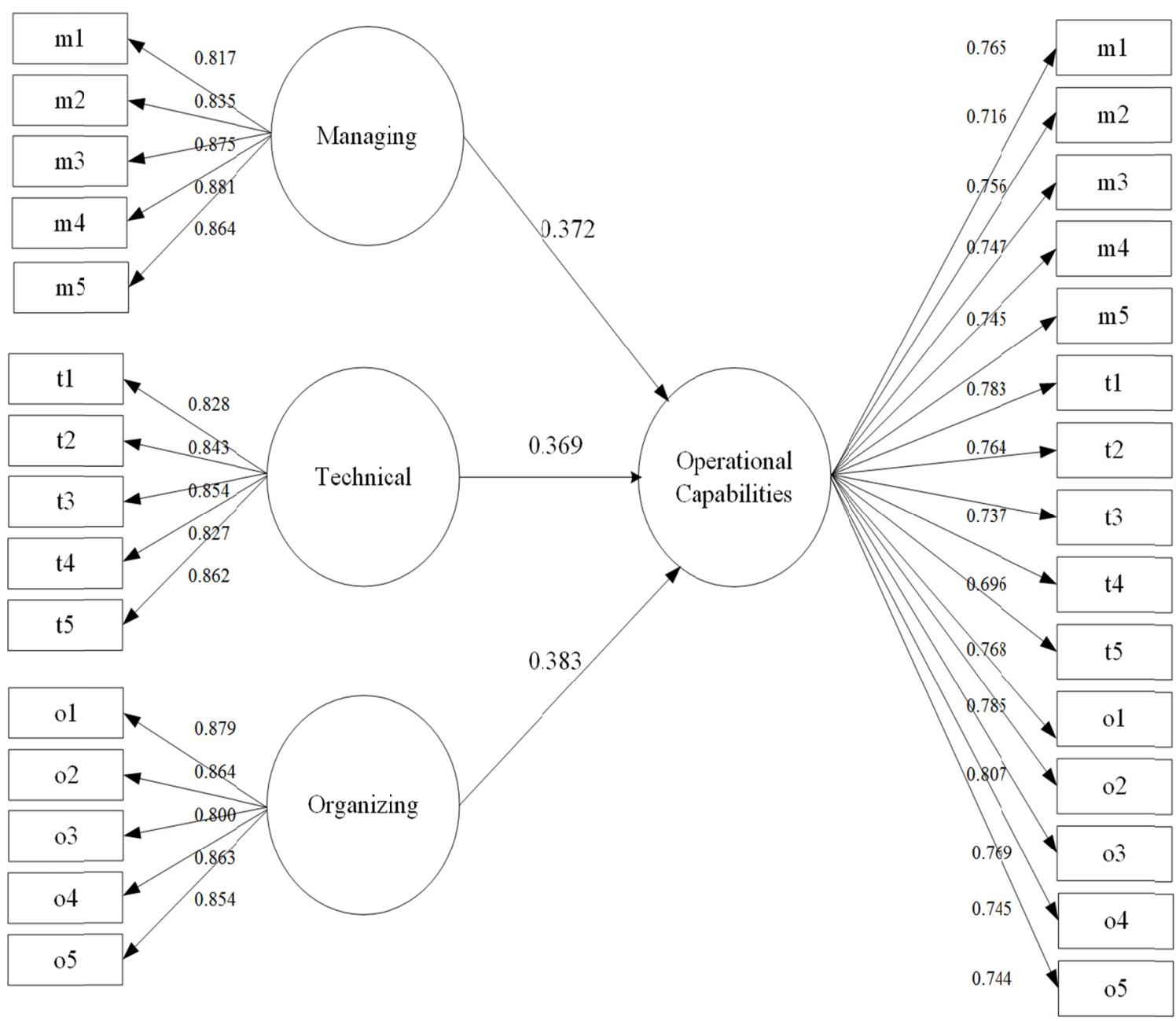

Figure 1. Conceptual representation of hierarchical component model for operational capabilities 


\section{Conclusion}

This study began with introducing main theoretical OC and identified a need for research, which summarized the reasoning for the research. The literature was reviewed with multiple research relevant domains, and also described an overview of the research and the following key research questions were then drawn from the previous research gaps, which are what $\mathrm{OC}$ is and how it works and what are composed of their sub-constructs in operational capabilities, and are those constructs supported by the empirical testing. Also, it described a proposed research model and an established measurement model using index of construction (Diamantopoulos \& Winklhofer, 2001). As a result, each measurement construct was emphasized and was then proposed. The measurement for constructs and their instruments were explained in detail about application software categories to be studied.

It summarized data descriptive and assessed the directionalities of indicators of the measurement models. In addition, each construct of $\mathrm{OC}$ was tested based upon block unidimensionality, which was expressed into organizing, managing, and technical capabilities as sub-dimensions of OC. Indicators in measurement models were tested to confirm validity, reliability and construct unidimensionality. In a measurement model, the theoretical realm on OC was established to be a reflective mode. Such findings indicate that this proposed research model has noteworthy to decide the strategic transformation for application software firms. Finally, it has been established that OC are best operationalized in a Type II (reflective-formative) orientation.

In addition to the academic implication on $\mathrm{OC}$, it has some managerial points in that manager in decision-making can practice the empirically tested sequential order procedure within mobile software application firms since their tested models come from the practical fields that composed of some of developers relevant to application development. This study is noteworthy for decision makers in application software firms at first and second hand. This empirical research has mainly covered the range of OC modeling outlined by Teece $(2007 ; 2009)$ and Helfat et al. (2007), therefore, relevant IT firms may apply its measurable model to similar firms' business model that own application software stores in order to identify the confronted situation of firms and take the available actions to the coming market changes. Especially, this research model may suggest the predictive strategic direction for IT firms that own their application stores. In addition, this study may be a basic reference to app developers, their firms, and app service providers under the fast changing mobile business environments.

The main contribution to this study is that it explores theoretically conceptual framework of OC. This study is, on the one, confirmatory in that it reproduces previous theoretical variables of $\mathrm{OC}$, on the other, is exploratory when modeling OC. In addition, this study develops and conducts a PLS-SEM application for the analysis of a higher-order level of construct for modeling higher-order component with the repeated indicator approach as an analytical process.

In the methodology section, this study mainly used mainly online survey to acquire data in order to test the model. Although great efforts were made to warrant data quality, both the quantitative and quantitative research will make this research much reliable. This study focuses on product or service development in the context of mobile application softwares and believes that these conducted research models will not generalize to other business settings, context, and units of analysis and will be further investigated. Any control variables such as respondents' and firms' information such as R\&D, job position, registration type, region census, etc., which could have influence on conceptualization and measurement of operational capabilities, and other industrial characteristics were not applied to the study. This study was taken a survey with non-managerial employees inclusive, which might lead to a bias since non-managerial staffs does usually not participate in making decision as a part of $\mathrm{OC}$, however, those might be some worthy to represent $\mathrm{OC}$ to measure day-to-day routines.

While there are numerous future researches, constructs on operational capabilities need to be developed further and to explore the other aspects not covered in this construct that influence OC in IT firms. A thorough and detailed investigation in $\mathrm{OC}$ into the various sub-dimensions, i.e., managing, organizing, and technical are necessary to explore further. It is necessary to conduct case studies to certify whether these empirical modeling could apply to the real business setting and how operational capabilities work under the various environment contexts.

\section{Acknowledgements}

The author would like to thank the anonymous reviewers as well as the editors for their constructive comments. 


\section{References}

Adner, R., \& Helfat, C. E. (2003). Corporate effects and dynamic managerial capabilities. Strategic Management Journal, 24(10), 1011-1025. http://dx.doi.org/10.1002/smj.331

Amit, R., \& Schoemaker, P. J. H. (1993). Strategic assets and organizational rent. Strategic Management Journal, 14(1), 33-46. http://dx.doi.org/10.1002/smj.4250140105

Andersen, T. J., \& Schrøder, P. W. (2010). Strategic risk management practice: How to deal effectively with major corporate exposures. http://dx.doi.org/10.1017/CBO9780511816017

Arend, R. J., \& Bromiley, P. (2009). Assessing the dynamic capabilities view: Spare change, everyone? Strategic Organization, 7(1), 75-90. http://dx.doi.org/10.1177/1476127008100132

Barney, J. (1991). Firm resources and sustained competitive advantage. Journal of Management, 17(1), 99-120. http://dx.doi.org/10.1177/014920639101700108

Barney, J., \& Hesterly, W. S. (2009). Strategic management and competitive advantage: Concepts and cases (3rd ed.). New Jersey, NJ: Prentice Hall.

Becker, J.-M., Klein, K., \& Wetzels, M. (2012). Hierarchical latent variable models in PLS-SEM: Guidelines for using reflective-formative type models. Long Range Planning, 45(5-6), 359-394. http://dx.doi.org/10.1016/j.lrp.2012.10.001

Berghman, L., Matthyssens, P., Streukens, S., \& Vandenbempt, K. (2013). Deliberate learning mechanisms for stimulating strategic innovation capacity. Long Range Planning, 46(1-2), 39-71. http://dx.doi.org/10.1016/j.lrp.2012.11.003

Bettis, R. A., \& Hitt, M. A. (1995). The new competitive landscape. Strategic Management Journal, 16(S1), 7-19. http://dx.doi.org/10.1002/smj.4250160915

Bollen, K., \& Lennox, R. (1991). Conventional wisdom on measurement: A structural equation perspective. Psychological Bulletin, 110(2), 305-314. http://dx.doi.org/10.1037/0033-2909.110.2.305

Bowman, C., \& Ambrosini, V. (2003). How the resource-based and the dynamic capability views of the firm inform corporate-level strategy. British Journal of Management, 14(4), 289-303. http://dx.doi.org/10.1111/j.1467-8551.2003.00380.x

Cenfetelli, R. T., \& Bassellier, G. (2009). Interpretation of formative measurement in information systems research. Mis Quarterly, 33(4), 689-707.

Chin, W. W. (1998). Commentary: Issues and opinion on structural equation modeling. MIS Quarterly (MISQ), 22(1), 7-16.

Collis, D. J. (1994). How valuable are organizational capabilities? Strategic Management Journal, 15(S1), 143-152. http://dx.doi.org/10.1002/smj.4250150910

Danneels, E. (2002). The dynamics of product innovation and firm competences. Strategic Management Journal, 23(12), 1095-1121. http://dx.doi.org/10.1002/smj.275

Davies, A., \& Brady, T. (2000). Organisational capabilities and learning in complex product systems: Towards repeatable solutions. Research Policy, 29(7-8), 931-953. http://dx.doi.org/10.1016/s0048-7333(00)00113-x

Day, G. S. (1994). The capabilities of market-driven organizations. Journal of Marketing, 58(4), 37-52. http://dx.doi.org/10.2307/1251915

Diamantopoulos, A., \& Winklhofer, H. M. (2001). Index construction with formative indicators: An alternative to scale development. Journal of Marketing, 38(2), 269-277. http://dx.doi.org/10.1509/jmkr.38.2.269.18845

Diamantopoulos, A., Riefler, P., \& Roth, K. P. (2008). Advancing formative measurement models. Journal of Business Research, 61(12), 1203-1218. http://dx.doi.org/10.1016/j.jbusres.2008.01.009

Drnevich, P. L., \& Kriauciunas, A. P. (2011). Clarifying the conditions and limits of the contributions of ordinary and dynamic capabilities to relative firm performance. Strategic Management Journal, 32(3), 254-279. http://dx.doi.org/10.1002/smj.882

Easterby-Smith, M., \& Prieto, I. M. (2008). Dynamic capabilities and knowledge management: An integrative role for learning? British Journal of Management, 19(3), 235-249. http://dx.doi.org/10.1111/j.1467-8551.2007.00543.x

Easterby-Smith, M., Lyles, M. A., \& Peteraf, M. A. (2009). Dynamic capabilities: Current debates and future 
directions. British Journal of Management, 20, S1-S8. http://dx.doi.org/10.1111/j.1467-8551.2008.00609.x

Eisenhardt, K. M., \& Brown, S. L. (1999). Patching. Restitching business portfolios in dynamic markets. Harvard Business Review, 77(3), 72-82.

Eisenhardt, K. M., \& Martin, J. A. (2000). Dynamic capabilities: what are they? Strategic Management Journal, 21(10-11), $1105-1121$. http://dx.doi.org/10.1002/1097-0266(200010/11)21:10/11<1105::AID-SMJ133>3.0.CO;2-E

Fischer, T., Gebauer, H., Gregory, M., Ren, G., \& Fleisch, E. (2010). Exploitation or exploration in service business development? Insights from a dynamic capabilities perspective. Journal of Service Management, 21(5), 591-624. http://dx.doi.org/10.1108/09564231011079066

Flynn, B. B., Wu, S. J., \& Melnyk, S. (2010). Operational capabilities: Hidden in plain view. Business Horizons, 53(3), 247-256. http://dx.doi.org/10.1016/j.bushor.2010.01.001

Fornell, C., \& Larcker, D. F. (1981). Evaluating structural equation models with unobservable variables and measurement error. Journal of Marketing Research, 18(1), 39-50. http://dx.doi.org/10.2307/3151312

Fowler, S. W., King, A. W., Marsh, S. J., \& Victor, B. (2000). Beyond products: New strategic imperatives for developing competencies in dynamic environments. Journal of Engineering and Technology Management, 17(3-4), 357-377. http://dx.doi.org/10.1016/s0923-4748(00)00029-1

Grant, R. M. (1996). Toward a knowledge-based theory of the firm. Strategic Management Journal, 17(S2), 109-122. http://dx.doi.org/10.1002/smj.4250171110

Hair, J. F., Sarstedt, M., Ringle, C. M., \& Mena, J. A. (2011). An assessment of the use of partial least squares structural equation modeling in marketing research. Journal of the Academy of Marketing Science, 40(3), 414-433. http://dx.doi.org/10.1007/s11747-011-0261-6

Hair, J. F., Hult, G. T. M., Ringle, C. M., \& Sarstedt, M. (2013). A primer on partial least squares structural equation modeling (PLS-SEM). SAGE Publications, Incorporated.

Hair, J. F., Sarstedt, M., Pieper, T. M., \& Ringle, C. M. (2012). The use of partial least squares structural equation modeling in strategic management research: A review of past practices and recommendations for future applications. Long Range Planning, 45(5-6), 320-340. http://dx.doi.org/10.1016/j.lrp.2012.09.008

Helfat, C. E., \& Peteraf, M. A. (2003). The dynamic resource-based view: Capability lifecycles. Strategic Management Journal, 24(10), 997-1010. http://dx.doi.org/10.1002/smj.332

Helfat, C. E., \& Peteraf, M. A. (2009). Understanding dynamic capabilities: Progress along a developmental path. Strategic Organization, 7(1), 91-102. http://dx.doi.org/10.1177/1476127008100133

Helfat, C. E., \& Winter, S. G. (2011). Untangling dynamic and operational capabilities: Strategy for the (n)ever-changing world. Strategic Management Journal, 32(11), 1243-1250. http://dx.doi.org/10.1002/smj.955

Helfat, C. E., Finkelstein, S., Mitchell, W., Peteraf, M. A., Singh, H., \& Teece, D. J. (2007). Dynamic capabilities: Understanding strategic change in organizations. Oxford, UK: Blackwell Publishing Ltd.

Henderson, R. M., \& Clark, K. B. (1990). Architectural innovation: The reconfiguration of existing product technologies and the failure of established firms. Administrative Science Quarterly, 35(1), 9-30. http://dx.doi.org/10.2307/2393549

Henderson, R., \& Cockburn, I. (1994). Measuring competence? Exploring firm effects in pharmaceutical research. Strategic Management Journal, 15(S1), 63-84. http://dx.doi.org/10.1002/smj.4250150906

Henseler, J., Ringle, C. M., \& Sinkovics, R. R. (2009). The use of partial least squares path modeling in international marketing. Advances in International Marketing, 20, 277-319. http://dx.doi.org/10.1108/S1474-7979(2009)0000020014

Jarvis, C. B., MacKenzie, S. B., \& Podsakoff, P. M. (2003). A critical review of construct indicators and measurement model misspecification in marketing and consumer research. Journal of Consumer Research, 30(2), 199-218. http://dx.doi.org/10.1086/376806

Kim, J. O., \& Mueller, C. W. (1978). Factor analysis: Statistical methods and practical issues (Quantitative applications in the social sciences series, book 14). London, UK: Sage Publication, Inc.

Kogut, B., \& Zander, U. (1992). Knowledge of the firm, combinative capabilities, and the replication of technology. Organization Science, 3(3), 383-397. http://dx.doi.org/10.1287/orsc.3.3.383 
Kogut, B., \& Zander, U. (1996). What firms do? Coordination, identity, and learning. Organization Science, 7(5), 502-518. http://dx.doi.org/10.1287/orsc.7.5.502

Kohli, A. K., \& Jaworski, B. J. (1990). Market orientation: The construct, research propositions, and managerial implications. Journal of Marketing, 54(2), 1-18. http://dx.doi.org/10.2307/1251866

Leonard-Barton, D. (1992). Core capabilities and core rigidities: A paradox in managing new product development. Strategic Management Journal, 13(S1), 111-125. http://dx.doi.org/10.1002/smj.4250131009

Li, S., Shang, J., \& Slaughter, S. A. (2010). Why do software firms fail? Capabilities, competitive actions, and firm survival in the software industry from 1995 to 2007. Information Systems Research, 21(3), 631-654. http://dx.doi.org/10.1287/isre.1100.0281

March, J. G. (1991). Exploration and exploitation in organizational learning. Organization Science, 2(1), 71-87. http://dx.doi.org/10.1287/orsc.2.1.71

Martin, J. A. (2011). Dynamic managerial capabilities and the multibusiness team: The role of episodic teams in executive leadership groups. Organization Science, 22(1), 118-140. http://dx.doi.org/10.1287/orsc.1090.0515

Narver, J. C., \& Slater, S. F. (1990). The effect of a market orientation on business profitability. Journal of Marketing, 54(4), 20-35. http://dx.doi.org/10.2307/1251757

Nelson, R. R., \& Winter, S. G. (1982). An evolutionary theory of economic change. Belknap Press.

Nunnally, J. C. (1978). Psychometric theory (McGraw-Hill series in psychology (2nd ed.). McGraw-Hill.

Okhuysen, G. A., \& Eisenhardt, K. M. (2002). Integrating knowledge in groups: How formal interventions enable flexibility. Organization Science, 13(4), 370-386. http://dx.doi.org/10.1287/orsc.13.4.370.2947

Pavlou, P. A., \& Sawy, El, O. A. (2006). From IT leveraging competence to competitive advantage in turbulent environments: The case of new product development. Information Systems Research, 17(3), 198-227. http://dx.doi.org/10.1287/isre.1060.0094

Pavlou, P. A., \& Sawy, El, O. A. (2011). Understanding the elusive black box of dynamic capabilities. Decision Sciences, 42(1), 239-273. http://dx.doi.org/10.1111/j.1540-5915.2010.00287.x

Penrose, E. T. (1959). The theory of the growth of the firm. New York, NJ: Wiley \& SonsWiley.

Peteraf, M. A. (1993). The cornerstones of competitive advantage: A resource-based view. Strategic Management Journal, 14(3), 179-191. http://dx.doi.org/10.1002/smj.4250140303

Pisano, G. P. (1994). Knowledge, integration, and the locus of learning: An empirical analysis of process development. Strategic Management Journal, 15(S1), 85-100. http://dx.doi.org/10.1002/smj.4250150907

Porter, M. E. (1985). Technology and competitive advantage. Journal of Business Strategy, 5(3), 60-78. http://dx.doi.org/10.1108/eb039075

Prahalad, C. K., \& Hamel, G. (1990). The core competence of the corporation. Harvard Business Review, 68(3), 79-91.

Protogerou, A., Caloghirou, Y., \& Lioukas, S. (2012). Dynamic capabilities and their indirect impact on firm performance. Industrial and Corporate Change, 21(3), 615-647. http://dx.doi.org/10.1093/icc/dtr049

Quinn, R. W., \& Dutton, J. E. (2005). Coordination as energy-in-conversation. Academy of Management Review, 30(1), 36-57. http://dx.doi.org/10.5465/amr.2005.15281422

Ringle, C. M., Sarstedt, M., \& Straub, D. (2012). A critical look at the use of PLS-SEM in MIS Quarterly. MIS Quarterly (MISQ), 36(1), 3-14.

Ringle, C. M., Wende, S., \& Becker, J. M. (n.d.). SmartPLS (v. 3.1.2). Retrieved from http://www.smartpls.de

Rumelt, R. P. (1984). Towards a strategic theory of the firm. Competitive strategic management (1984) Lamb, $R B$ (pp. 556-570). Englewood Cliffs, NJ: Prentice Hall.

Song, X. M., \& Parry, M. E. (1997). A cross-national comparative study of new product development processes: Japan and the United. Journal of Marketing, 61(2), 1-18. http://dx.doi.org/10.2307/1251827

Spanos, Y. E., \& Lioukas, S. (2001). An examination into the causal logic of rent generation: Contrasting porter's competitive strategy framework and the resource-based perspective. Strategic Management Journal, 22(10), 907-934. http://dx.doi.org/10.1002/smj.174 
Swink, M., \& Hegarty, W. H. (1998). Core manufacturing capabilities and their links to product differentiation. International Journal of Operations \& Production Management, 18(4), 374-396. http://dx.doi.org/10.1108/01443579810199748

Teece, D. J. (1982). Towards an economic theory of the multiproduct firm. Journal of Economic Behavior \& Organization, 3(1), 39-63. http://dx.doi.org/10.1016/0167-2681(82)90003-8

Teece, D. J. (2007). Explicating dynamic capabilities: The nature and microfoundations of (sustainable) enterprise performance. Strategic Management Journal, 28(13), 1319-1350. http://dx.doi.org/10.1002/smj.640

Teece, D. J. (2009). Dynamic capabilities and strategic management: Organizing for innovation and growth. OUP Oxford.

Teece, D. J. (2011). Achieving integration of the business school curriculum using the dynamic capabilities framework. Journal of Management Development, 30(5). http://dx.doi.org/10.1108/02621711111133019

Teece, D. J., Pisano, G., \& Shuen, A. (1997). Dynamic capabilities and strategic management. Strategic Management Journal, 18(7), 509-533. http://dx.doi.org/10.1002/(sici)1097-0266(199708)18:7<509::aid-smj882>3.0.co;2-z

Tenenhaus, M., Vinzi, V. E., Chatelin, Y. M., \& Lauro, C. (2005). PLS path modeling. Computational Statistics \& Data Analysis, 48(1), 159-205. http://dx.doi.org/10.1016/j.csda.2004.03.005

Wang, C. L., \& Ahmed, P. K. (2007). Dynamic capabilities: A review and research agenda. International Journal of Management Reviews, 9(1), 31-51. http://dx.doi.org/10.1111/j.1468-2370.2007.00201.x

Wernerfelt, B. (1984). A resource-based view of the firm. Strategic Management Journal, 5(2), 171-180. http://dx.doi.org/10.1002/smj.4250050207

Wetzels, M. (2009). Using PLS path modeling for assessing hierarchical construct models: guidelines and empirical illustration. Mis Quarterly, 33(1), 177-195.

Winter, S. G. (2000). The satisficing principle in capability learning. Strategic Management Journal, 21(10-11), 981-996. http://dx.doi.org/10.1002/1097-0266(200010/11)21:10/11<981::AID-SMJ125>3.0.CO;2-4

Winter, S. G. (2003). Understanding dynamic capabilities. Strategic Management Journal, 24(10), 991-995. http://dx.doi.org/10.1002/smj.318

Wold, H. (1980). Model construction and evaluation when theoretical knowledge is scarce: Theory and application of partial least squares. Evaluation of Econometric Models, 47-74, National Bureau of Economic Research, Inc. http://dx.doi.org/10.1016/b978-0-12-416550-2.50007-8

Wu, S. J., Melnyk, S. A., \& Flynn, B. B. (2010). Operational capabilities: The secret ingredient. Decision Sciences, 41(4), 721-754. http://dx.doi.org/10.1111/j.1540-5915.2010.00294.x

Wu, S. J., Melnyk, S. A., \& Swink, M. (2012). An empirical investigation of the combinatorial nature of operational practices and operational capabilities: Compensatory or additive? International Journal of Operations \& Production Management, 32(2). http://doi.org/10.1108/01443571211208605

Zahra, S. A., Sapienza, H. J., \& Davidsson, P. (2006). Entrepreneurship and dynamic capabilities: A review, model and research agenda. Journal of Management Studies, 43(4), 917-955. http://dx.doi.org/10.1111/j.1467-6486.2006.00616.x

Zollo, M., \& Winter, S. G. (2002). Deliberate learning and the evolution of dynamic capabilities. Organization Science, 13(3), 339-351. http://dx.doi.org/10.1287/orsc.13.3.339.2780

\section{Copyrights}

Copyright for this article is retained by the author(s), with first publication rights granted to the journal.

This is an open-access article distributed under the terms and conditions of the Creative Commons Attribution license (http://creativecommons.org/licenses/by/3.0/). 